\title{
Foreword: A Maimonidean Kabbalist
}

\author{
Warren Zev Harvey, Hebrew University of Jerusalem
}

Moshe Idel, the Max Cooper Professor Emeritus of Jewish Thought at the Hebrew University of Jerusalem, was born in Târgu Neamț, Romania, in 1947. He immigrated to Israel in 1963, majored in Hebrew and English literatures at Haifa University (BA, 1970), and studied Jewish philosophy and Kabbalah at the Hebrew University of Jerusalem under Shlomo Pines and Ephraim Gottlieb (PhD, 1976). He has published scores of books and hundreds of essays, including the ground-breaking Kabbalah: New Perspectives (1988), which has been translated into nine languages. He is an Israel Prize laureate (1999), an EMET Prize laureate (2002), and a member of the Israel Academy of Sciences and Humanities (2006).

Idel's research ranges far and wide, from the Bible and Talmud through the medieval Kabbalists and philosophers to Renaissance humanism, Safed mysticism, Sabbatianism, Hasidism, and post-modernism. However, at the centre of his work is the "prophetic" or "ecstatic" Kabbalah of Rabbi Abraham Abulafia (1240-1291). His doctoral dissertation, written in Hebrew under the supervision of Shlomo Pines, was entitled "Rabbi Abraham Abulafia's Works and Doctrine" (1976). Among his English books on Abulafia are The Mystical Experience in Abraham Abulafia (1988), Studies in Ecstatic Kabbalah (1988), and Language, Torah, and Hermeneutics in Abraham Abulafia (1989).

Idel was not the first person to appreciate Abulafia's importance. In 1919, Gershom Scholem, who later founded the discipline of Kabbalah studies at the Hebrew University of Jerusalem, began a doctoral dissertation at the University of Munich on the theory of language in the works of Abulafia and other Kabbalists. However, he abandoned this project because he had difficulty deciphering Abulafia's arcane texts, and instead wrote about Sefer ha-Bahir (1922). ${ }^{1}$ In 1925, Scholem composed a report for the famed Hebrew poet Hayyim Nahman Bialik in which he assessed the state of research in Jewish mysticism. When he came to mention the Kabbalistic works that urgently needed to be published, he lauded "the books of Rabbi Abraham Abulafia," describing him as "the most important personality among all the early [Kabbalists] known to us today."2 In his Major Trends in Jewish Mysticism, published in 1941, Scholem devoted a significant chapter to Abulafia, writing about his "very great" influence and praising his "remarkable combination of logical power, pellucid style, deep insight, and highly colored abstruseness." ${ }^{3}$ However, after Major Trends,

1 Gershom Scholem, From Berlin to Jerusalem: Memories of My Youth, trans. Harry Zohn (New York: Schocken, 1980), 115.

2 Gershom Scholem, Devarim be-Go (Tel-Aviv: Am Oved, 1975), 62.

3 Gershom Scholem, Major Trends in Jewish Mysticism (New York: Schocken, 1941), 124. 
his interest in Abulafia waned..$^{4}$ Idel sees Scholem's decreased interest in Abulafia as the result of his growing tendency to portray Kabbalah as an essentially theosophical tradition. However, I am inclined to see it as being due to Abulafia's overt Maimonideanism. In Major Trends and later works, Scholem contrasted the spiritually meaningful Kabbalah with "sterile” Maimonideanism. Abulafia's stunning integration of Kabbalah and Maimonideanism gives the lie to Scholem's contrast. ${ }^{5}$

Idel wrote his doctoral dissertation on Abulafia not under Scholem, the master of Kabbalah, but under Pines, the savant of medieval Arabic and Hebrew philosophy. Why Pines instead of Scholem? First, Scholem had retired from teaching in 1965, five years before Idel came to Jerusalem, although he was still active and supervised the dissertation of Idel's friend and colleague Yehuda Liebes (1976). Second, Idel was initially interested in philosophy and intended to study a philosophical subject with Pines, but Ephraim Gottlieb aroused his interest in Kabbalah. Gottlieb supervised Idel's research on Abulafia until his untimely death in 1973, at which point Pines took over his supervision.

Be this as it may, one might also imagine that Idel was drawn to Pines because of a similarity in their attitudes to scholarship. He shared with Pines an anarchic suspicion of all theories. He has spoken of the "important lesson" he learned as a young scholar researching Kabbalistic texts and trying to understand them in light of the theories of Scholem, Mircea Eliade, and others: "The theories [...] simply don't work." No theories work. "The minute you try to apply [a theory] to the text, you [...] do violence to [it] [...]. You must remain free to listen to the text." 6

In contrast to Pines, Scholem, like Hegel and Schelling, was a theorist. His brilliant dialectical theory of the history of religion is confidently set down in his Major Trends. ${ }^{7}$ To put things too simplistically: Scholem's approach was dogmatic, Pines's was sceptical.

4 There are two exceptions: (1) From January to March 1965, Scholem lectured on Abulafia at the Hebrew University of Jerusalem. See Gershom Scholem, The Kabbalah of Sefer ha-Temunah and of Abraham Abulafia [Hebrew,] ed. Y. Ben-Shlomo (Jerusalem: Academon, 1965); (2) In 1970, Scholem spoke at the Eranos conference in Ascona on the Kabbalistic theory of language, focusing on Abulafia. See Gershom Scholem, "The Name of God and the Linguistic Theory of the Kabbalah," trans. Simon Pleasance, Diogenes 79 (Fall, 1972): 59-80; 80 (Winter, 1972): 164-94. The Eranos talk was based in part on Scholem's aborted Munich doctoral dissertation. See Moshe Idel, Old Words, New Mirrors: On Jewish Mysticism and Twentieth-Century Thought (Philadelphia: University of Pennsylvania Press, 2010): 168-75.

5 See my essays "Idel on Spinoza," Journal for the Study of Religions and Ideologies 18 (2007): 88-94 and "Two Approaches to Evil in History," in The Impact of the Holocaust on Jewish Theology, ed. Steven T. Katz (New York: New York University Press, 2005): 194-201. On Scholem's later tendency to see Kabbalah as "a pre-eminently symbolic, theosophical, and Gnostic-like lore," see below, p. 12.

6 Moshe Idel, Representing God, ed. Hava Tirosh-Samuelson and Aaron W. Hughes (Leiden: Brill, 2014), 156-60. Cf. my “The Versatility of Contemporary Jewish Philosophy," in The Future of Jewish Philosophy, ed. Hava Tirosh-Samuelson and Aaron W. Hughes (Leiden: Brill, 2018): 47-48.

7 Scholem, Major Trends, 7-10. 
Like Pines and Idel, Abulafia was a sceptic. His scepticism was rooted in his theory of the imagination, which was essentially Maimonidean, although liberally spiked with alphabetology and numerology. Following Maimonides, he held that all knowledge, including prophecy, is dependent on the imagination, which mediates between the sensibilia and the intelligibilia. Abulafia notes that the Hebrew word dimyon ("imagination") is an anagram of the Latin medium ${ }^{8}$ ("middle"). The imagination, however, is a corporeal faculty that "never apprehends any true reality." 9 It is "a large-boned ass [hamor garem], crouching between the boundaries" (Genesis 49:14); that is, it is a body (= gerem) composed of matter (= homer) mediating between the sensible world and the intellect. Since all our knowledge is dependent on this large-boned ass, we should never expect it to be apodictic. ${ }^{10}$ Moreover, Abulafia continues, the true "secret" (sod) of the imagination is indicated by another one of its anagrams: demon. The imagination is demonic. It is Satan! He sabotages our attempts to achieve knowledge; thus, error is inevitable, and scepticism warranted. ${ }^{11}$ Idel writes of "an affinity between imagination and doubt." ${ }^{12}$ He explains that according to Abulafia, it is a "perennial problem of human nature" that the "perfect type of cognition" is obstructed by the imagination. ${ }^{13}$

Idel stresses the decisive importance of Maimonides's Guide of the Perplexed for Abulafia. Throughout his life, Abulafia studied and taught the Guide. In 1261, he studied it in Capua with the Maimonidean philosopher Hillel of Verona. In Spain, Italy, Greece, and elsewhere, he taught it to young and old, scholars and layfolk. He wrote three different commentaries on the secrets of the Guide during the years 1273 to 1280. Maimonides's presence is felt in all of Abulafia's works. Indeed, as Idel puts it, Abulafia is "part of the history of Maimonideanism." ${ }^{14}$ Furthermore, Idel observes, Abulafia saw Maimonides not only as a philosophical source, but also as a Kabbalistic one. According to Abulafia's own testimony, his Kabbalah was based on two main sources: Sefer Yeșirah and the Guide of the Perplexed. ${ }^{15}$ "It would not be an exaggeration," Idel writes, to see Abulafia’s Kabbalah as "gravitating around central concepts found in the Guide."16 In Abulafia's eyes, Maimonides was "the divine rabbi" (ha-rav ha-elohi). ${ }^{17}$

\footnotetext{
8 To be precise, the anagram is mediun or medion (דמיון = מדיון), which presumably reflects an old vulgar form of medium.

9 See below, p. 150.

10 See below, p. 150.

11 See below, p. 150: dimyon = demon (דמיון = דימון). See Maimonides, The Guide of the Perplexed, trans. Shlomo Pines (Chicago: University of Chicago Press, 1963), 2:12, p. 280 (imagination = evil impulse); and 3:22, p. 489 (evil impulse = Satan). Cf. 2:30, p. 356 (Samael = Satan).

12 See below, p. 148, n. 154.

13 See below, p. 132.

14 See below, p. 45.

15 See below, p. 85.

16 See below, p. 77.

17 See below, p. 89.
} 
According to Idel, Abulafia, at least in some of his works, adopted a complex esoteric style of writing similar to that used by Maimonides in his Guide, which was analysed in detail by Leo Strauss in several studies, notably Persecution and the Art of Writing (1952). Idel argues that Abulafia's works must be read with precisely the same strategies that Strauss recommended for reading the Guide. However, Idel reminds us, Abulafia's texts are exceptionally recondite, since they combine philosophical esotericism, such as that found in the Guide, with different varieties of Kabbalistic esotericism. ${ }^{18}$

At one point, Abulafia remarks that he does not call Maimonides's book Moreh ha-Nevukhim ("The Guide of the Perplexed"), but rather Makkeh ha-Ruhanim ("The Striker of the Spiritual Ones"). The two phrases, Abulafia explains, are interchangeable, since they have the same numerical value: 384. Abulafia discloses that he calls the book "The Striker of the Spiritual Ones" because "it adds the spirit of wisdom [ruah hokhmah] to each devotee of knowledge [ba'al madda'], and says to him: grow!" Abulafia's words here allude to an astrological statement in Genesis Rabbah 10:6: "There is no herb that does not have a star in heaven that strikes it, and says to it: grow!" Here, Abulafia's point is that Maimonides's Guide, like a star in heaven, strikes the scientist or philosopher and inspires him with "the spirit of wisdom." It raises him from madda' (= ratio) to ruah hokhmah ("the spirit of wisdom"). ${ }^{19}$ Now, this phrase, "the spirit of wisdom," alludes to two biblical texts. The first text refers to the extraordinary spiritual power of Moses: "And Joshua the son of Nun was full of the spirit of wisdom, for Moses had laid his hands upon him” (Deuteronomy 34:9). In the Bible, it is Moses ben Amram who imparts the spirit of wisdom; in Abulafia's text, it is Moses ben Maimon. The second text refers to the famous messianic verses in Isaiah: "And there shall come forth a shoot out of the stock of Jesse [...]. And the spirit of the Lord shall rest upon him, the spirit of wisdom and understanding” (Isaiah 11:1-2). The Guide thus fulfils a messianic mission by striking its readers and elevating them from "knowledge" or "science" to "the spirit of wisdom.” Abulafia's numerical games can often be pushed beyond their surface-level meaning. If we ask the meaning of 384, we discover that it equals "the messiah of YHWH"!20

The parallel between Moses ben Amram and Moses ben Maimon is often cited by Abulafia, as it has been cited by Maimonideans throughout the ages. In a poem discussed by Idel, Abulafia writes: "Read the religion [dat] of [Moses] the son of Amram together with the religion [dat] of Moses son of Maimon." Idel writes that this line expresses "the dramatic change generated by the emergence of the new philosophical religion." He observes that according to the poem, the "two religions," the biblical and the philosophical, are "almost independent," but "one should study them together." In Idel's words, Abulafia sought to make a "synthesis" of the two reli-

18 See below, pp. 13-17.

19 See below, p. 69. Cf. Maimonides, Guide, 2:10, 269-270.

מורה הנבוכים = מכה הרוחנים = 384 = משיח יהו"ה 20 
gions. ${ }^{21}$ It may, however, be more precise to say that he wished to dissolve the former into the latter.

Indeed, the evidence that Idel marshals shows that Abulafia was consistently radical in his reinterpretations of biblical and rabbinic religion and deserves to be counted among the boldest of the Maimonideans. For example, Idel gives a detailed analysis of Abulafia's multiple interpretations of a notorious rabbinic homily according to which the Serpent in the Garden of Eden had sexual relations with Eve and cast pollution into her and her descendants. This homily states that the pollution of the Israelites who stood at Mount Sinai has ceased, but that that of the Gentiles continues (BT Šabbat 146a and parallels); it is the closest text in the Jewish tradition to the Christian doctrine of Original Sin. Like this doctrine, it is problematic because of its exclusivism. However, Maimonides had already provided an allegorical interpretation that mitigates the exclusivism, although he did so cryptically. According to his interpretation, the homily concerns morality, not history: the Serpent's pollution symbolises imaginary desires, and standing at Mount Sinai symbolises true ideas. The lesson is that imaginary desires lead human beings to sin, but true ideas prevent them from sinning. ${ }^{22}$ Abulafia elaborates on Maimonides's interpretation. First, referring to certain rabbis who indulged in magic, Abulafia writes that the Serpent has cast pollution into them; "their brain is polluted," they did not stand at Sinai, even though they are rabbis, and they will have no cure until they do. Here, it is explained by means of a clever letterplay that the name "Mount Sinai" (Har Sinai) derives from the word "bridle" (resen) and means "self-restraint." The antidote for the maladies caused by the imaginary desires is self-restraint, and self-restraint is concomitant to true ideas. ${ }^{23}$ Second, in discussing the homily, Abulafia speaks of human beings (= adam), not Israelites. He also identifies standing at Mount Sinai with eating of the Tree of Life: both acts symbolise the acquisition of true ideas, but the former is particularistic and the latter universalistic. ${ }^{24}$ Third, in a mind-boggling revision of the homily, Abulafia writes: "The pollution of the Israelites who stood at Mount Sinai has not ceased!" He then continues: "In order to find a way to make the pollution cease, the books [of King Solomon] were written.” According to the radically revised homily, Mount Sinai was not sufficient to stop ignorance and immorality in Israel. Therefore, King Solomon, the wisest of all human beings, wrote three books: Proverbs, on ethics; Ecclesiastes, on physics; and the Song of Songs, on metaphysics. Abulafia may be hinting that the books of Solomon represent progress beyond those of Moses. ${ }^{25}$ Fourth, in one of his discussions of the homily, Abulafia ridicules those who think it should be taken literally: "How can any person in the

21 See below, pp. 21-22. The poem was written for the Feast of Weeks by a certain Rabbi Abraham, whom Idel has convincingly identified as Abulafia.

22 Guide 2:30, pp. 356-57.

23 See below, pp. 130-31: הר סיני = רסן.

24 See below, p. 132-33.

25 See below, pp. 131-32; cf. p. 217 (on “Moses, Joshua, David, and Solomon”). 
world be called 'wise' who thinks this homily is to be taken literally, and the Serpent [...] had sexual relations with Eve?!" Idel writes that Abulafia's sharp criticisms of the literal meaning of certain rabbinic texts are unprecedented in both the Kabbalistic and the Maimonidean literature of his time. These criticisms, in Idel's opinion, reflect Abulafia's "intellectual repulsion" in the face of "foolish" myths. ${ }^{26}$

Abulafia emerges from Idel's discussions as a trenchant and morally sensitive thinker who does not hesitate to reinterpret an unreasonable scriptural or rabbinic text. As he punned, "A philosopher will examine the literal meanings [pešațim] and know they are words said for fools [țippešim].” Pešaț ("literal meaning”) is an anagram of tippeš (“fool”). ${ }^{27} \mathrm{He}$ also emerges as an independent-minded Kabbalist and Maimonidean. His thought shows how far the Kabbalah can go in the direction of philosophy, and how far philosophy can go in the direction of Kabbalah.

In sum, Abulafia was a Maimonidean Kabbalist. This phrase may sound like an oxymoron to many Maimonideans and Kabbalists. Nonetheless, it describes Abulafia accurately. Abulafia was bold not only as a thinker, but also as a man of action. In 1258, at the age of eighteen, he journeyed from Spain to the Land of Israel, seeking to find the River Sambation and to discover the lost Ten Tribes. Considering himself a prophet and a messiah, he went to Rome in 1280 in order to confront Pope Nicholas III. Although orders were issued to have him executed, Abulafia fearlessly entered the papal palace in Soriano, but then learned that the pope had suddenly died (perhaps from anxiety over his threatened visit).

Abulafia's prophetic and messianic pretensions, coupled with his radical Maimonideanism, incurred the antagonism of many. Among his antagonists was the celebrated Talmudist Rabbi Solomon ben Abraham ibn Adret of Barcelona, who put him under the ban sometime in the 1280s. In a remark from 1273 that sounds like it was uttered by Spinoza, Abulafia referred to the persecution he was suffering for his ideas: "They call me a heretic and unbeliever because I have worshipped God in truth and not according to the imagination of the people who walk in darkness [...]. I shall not forsake the ways of truth for those of falsehood."28

The Barcelona ban against Abulafia was more effective than the Amsterdam ban against Spinoza. While Spinoza's books have often been printed and extensively discussed, most of Abulafia's books were not printed until recent years and his Kabbalah was studied only clandestinely. Despite the effectiveness of the ban, however, Abulafia did succeed in having an influence on some major thinkers and scholars, such as Ramon Llull, Meister Eckhart, Joseph Kaspi, Moses Narboni, Johanan Alemanno, Giovanni Pico della Mirandola, Moses Cordovero, Hayyim Vițal, Spinoza, Israel Ba'al Shem Tov, Elijah Gaon of Vilna, and Menahem Mendel of Shklov. In the

26 See below, pp. 134-35.

27 See below, p. 116: פשט = טפש This anagram was a favourite of Abraham Joshua Heschel. See Michael Marmur, Abraham Joshua Heschel and the Sources of Wonder (Toronto: University of Toronto Press, 2016), 21.

28 See below, pp. 110-11. 
contemporary era, important authors, including Yvan Goll, Jacques Derrida, and Umberto Eco, have been fascinated by him. ${ }^{29}$ The present book by his pre-eminent interpreter explains why Rabbi Abraham Abulafia merits our attention too.

29 See below, pp. 307-8. Cf. R. Barbara Gitenstein, Apocalyptic Messianism and Contemporary JewishAmerican Poetry (Albany, NY: SUNY Press, 1985), 133, s.v. Abulafia, Abulafianism; and Christine A. Meilicke, “Abulafianism among the Counterculture Kabbalists,” Jewish Studies Quarterly 9 (2002): 71-101. 
